\title{
LIFE a GIFT
}

\section{Thimappa Hegde}

Department of Neurosurgery, Narayana Hrudayala, Bangalore, Karnataka, India. E-mail: thegde@gmail.com

Dr. Thimappa Hegde is a distinguished neurosurgeon, and is presently working as the Director of Narayana Institute of Neurosciences, Bangalore. He finished his neurosurgery residency from NIMHANS, Bangalore. He continued as a faculty till 2003, where he was instrumental in starting Stereotactic and Functional Neurosurgery. Apart from being an excellent neurosurgeon, he has a keen interest in personality development, and is invited by various organizations as a guest speaker and motivator. He was invited by the Vatican to speak at an International Meeting at the Vatican City and had a special audience with the POPE His Holiness John Paul II. With his keen interest in spirituality, Dr. Hegde has scaled new heights, despite having a very busy neurosurgical practice.

As medical professionals, every day we encounter disease, disability, and death. We must never grow indifferent to them. Disabilities trouble us and death unnerves us with its unpredictability. For us as neurosurgeons, the most difficult aspect of our job has always been having to tell family members about a patient's real health status. If disease and death only afflicted the old, then there would be some reprieve; however, in our profession, we know that disease and death do not spare anyone and both can strike at anytime without warning.

So, how does one retain one's sanity, in this transient world and, as a medical professional, continue to perform our duties day in and day out? One powerful way is "the attitude of gratitude" when we realize how lucky we are to be blessed with good health!

As it is virtually impossible to feel grateful and miserable at the same time, we need to begin every waking day with the feeling "How lucky we are!"

For me, this is a song of a grateful heart.

\begin{tabular}{|l|l|}
\hline \multicolumn{2}{|c|}{ Access this article online } \\
\hline Quick Response Code: & Website: \\
\hline & www.ijns.in \\
\cline { 2 - 2 } & \\
\hline
\end{tabular}

\section{DRINKING FROM MY SAUCER}

"I've never made a fortune

and it's probably too late now.

But I don't worry about that much,

I'm happy anyhow.

And as I go along life's way,

I'm reaping better than I sowed.

I'm drinking from my saucer,

'Cause my cup has overflowed."

It is not uncommon to ask for directions when traveling to a location. So, when even for something as simple as a shopping experience, in a new locality, we ask for directions, why do we prefer to tackle life with all its complexity on our own, especially when we know that our time on earth is limited?

Many look to scriptures and writings by Masters to guide them, and I would like to share one which has moved me. This Master has said that we need to fulfill three debts before we leave this world. The first is to our parents, second to the society we live in, and the third to our teachers by maximizing our potential.

Debt to one's parents

It is clear to all of us that no one has done more for us than our parents. In return, we need to factor their needs as very important and treat them with great respect and reverence. Many traditions teach that we seek their good wishes in all that we do. It is important to let them know that "I am there for you."

Those who do not have living parents can offer services to the elderly and be able to treat any older person as a parent.

The ultimate fulfillment for parents would be when they hear from others that they are so lucky to have a son or a daughter like you.

\section{Debt to the community}

We have received so much from the community we live in today. In fact, we are standing on the shoulders of those who have served the community in the past. Can our mission be to give far more than what we have received? This can be done by an attitudinal shift. Whatever we do, can it be as an act of love? It then becomes relatively 
effortless. The best comes out and we enjoy what we do. More important, the outcome does not matter as there is a fulfillment in the act itself.

\section{Debt to our teachers}

This is the most difficult to fulfill! We are here to attain our fullest potential. We are all differently endowed and have unique roles to play according to our abilities.

This quest should not make us serious as it is against the very purpose of our lives. We are here to enjoy life and to celebrate to the full all the gifts that life provides us.

Here too, we need a guide. We do not become good neurosurgeons, if not for our teachers. So also, this quest requires a guide who may be in the form of a book or a teacher, whose life itself is a source of inspiration.
Patanjali, about 5000 years ago in Yoga Sutras, has said very aptly,

"When you are inspired by some great purpose, some extraordinary project, your mind transcends limitations, your consciousness expands in every direction. Dormant forces, faculties and talents become alive, and you discover yourself to be a greater person by far than you ever dreamed yourself to be."

And French philosopher Teilhard de Chardin says, "We are not human beings with an occasional spiritual experience but spiritual beings who are not aware of our true nature."

How to cite this article: Hegde T. LIFE a GIFT. Indian J

Neurosurg 2012;1:187-8.

Announcement

\section{Android App}

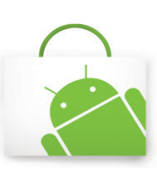

